\title{
EBV Incidence in Diffuse Large B-Cell Lymphoma: A Single Center Descriptive Study
}

\author{
Diffüz Büyük B Hücreli Lenfomada EBV Insidansının \\ Değerlendirilmesi: Tek Merkezli Deskriptif Bir Çalışma
}

Abdulkadir Yasir Bahar ${ }^{1}$, Ulku Kazanci',

${ }^{1}$ Kahramanmaras Sütçü Imam University, School of Medicine, Department of Pathology, Kahramanmaraş, Turkey"

Geliş Tarihi/Received: 18 March 2019 Kabul Tarihi/Accepted: 12 July 2019

Address correspondence to: Abdulkadir Yasir Bahar, Kahramanmaraş Sütçü İmam University, School of Medicine, Department of Pathology, Kahramanmaraş, Turkey e-mail: ayasirbahar@gmail.com

\section{ORCID}

Abdulkadir Yasir Bahar

https://orcid.org/0000-0002-6963-3389 Ulku Kazanci

https://orcid.org/0000-0003-3769-1338

\begin{abstract}
Öz
Amaç: Diffüz büyük B hücreli lenfoma (DBBHL) hastalarında klinik ve prognostik heterojenite gözlendiğinden prognostik ve prediktif faktörlerin belirlenmesi hayati önem taşımaktadır. Bu faktörlerin sıklığı coğrafi ve etnik farklılıklar göstermektedir. WHO 2017 revize 4. baskısına dayanarak merkezimizde R-CHOP ile tedavi edilen DLBCL hastalarının prognostik, prediktif faktörlerini ve EBV insidansını yeniden değerlendirmeyi ve tartışmayı amaçladık.

Hastalar ve Yöntem: Hastanemizde 2007-2017 yılları arasında tanı almış ve R-CHOP ile tedavi edilmiş DLBCL-NOS'lu hastalar çalışmaya dahil edildi. 104 hastada; CD10, CD5, CD30, BCL-2, BCL-6, MUM-1, MYC, LMP-1, EBNA-2, Ki-67 ve p53 ekspresyonlarını immünohistokimyal olarak ve EBV encoded RNA (EBER) in situ hibridizasyon ile değerlendirildi. Revize Uluslararası Prognostik Indeks (R-IPI) skoru ve genel sağkalım süresi hesaplandı.

Bulgular: Calıșmada 56 erkek (\% 53,8) ve 48 kadın (\% 46,2) mevcuttu. Ortalama yas 64,5 idi. Hastaların $\%$ 59,6'sında hastalık nodal başlangıcı iken, \% 40,4'ünde ekstranodal başlangı̨̧ mevcuttu. GCB subtipin $\% 26,5$ 'inde, non-GCB subtipin \% 43,6'sında ileri stage (III-IV) mevcuttu ( $p=0,049$ ). Yüksek R-IPI skor, GCB subtipte $\% 40$ ve non-GCB subtipte $\% 54,5$ oranında gözlendi $(p=0,028)$. Non-GCB subtipte sağkalım anlamlı olarak düşüktü (log-rank testi $p=0,003$ ). Batı popülasyonlarında bildirildiği gibi EBV sıklığı yaklaşık \% 3 idi. Double ekspressör lenfoma (DEL) sıklığı \% 8,7 idi ve bu durumun inferior sağkalım ile ilişkili olduğu gösterildi $(p=0,045)$. De novo CD5 + DLBCL oranı \% 13 olarak bulundu ve aynı zamanda inferior sağkalım ile de ilişkili idi $(p=0,013)$. CD30 + DLBCL oranını da \% 11,5 olarak bulundu, ancak prognoz ile anlamlı bir ilişsi kurulamadı.

Sonuç: DLBCL-NOS'da ayrıntılı alt tipleme ve prognostik faktörlerin detaylandırılmasını gerekmektedir. Çalışmamızda DEL durumu ve De novo CD5 + DBBHL sıklığı ile düşük sağkalım arasında ilişki gösterilirken. CD30 + DLBCL ile prognoz arasında anlamlı bir ilişki gösterilememiştir. Ayrıca EBV pozitif 3 olgu saptanmış olup bunlardan 2'si yeni sınıflamaya göre 'EBV pozitif büyük B hücreli lenfoma' olarak sınıflanması uygundur.
\end{abstract}

Anahtar Kelimeler: Diffüz büyük B hücreli lenfoma, prognostik faktörler, sağkalım \begin{abstract}
Aim: Since clinical and prognostic heterogeneity is observed in diffuse large B-cell lymphoma (DLBCL) patients, it is vital to determine its prognostic and predictive factors. The frequency of these factors varies geographically and ethnically. We aimed to reevaluate and discuss the prognostic and predictive factors of DLBCL patients who have been treated with R-CHOP in our center based on the WHO 2017 revised 4th edition. We also investigated the incidence of EBV in DLBCL-NOS.

Patients and Methods: Patients with DLBCL-NOS diagnosed previously in our hospital between 2007 2017 and treated with R-CHOP were included in the study. We evaluated the expressions of CD10, CD5, CD30, BCL-2, BCL-6, MUM-1, MYC, LMP-1, EBNA-2, Ki-67, and p53, by immunohistochemistry, and EBV encoded RNA by in situ hybridization in 104 cases of DLBCL-NOS. The Revised International Prognostic Index (R-IPI) score and the overall survival time was calculated.

Results: The study included 56 men $(53.8 \%)$ and 48 women $(46.2 \%)$. The median age was 64.5 years. In $59.6 \%$ of the patients, the disease had a nodal beginning, whereas in $40.4 \%$ of the patients it had an extranodal presentation. High stage (III-IV) was present in $26.5 \%$ of the GCB subtype and $43.6 \%$ of nonGCB subtype $(p=0.049)$. A high R-IPI score was observed in $40 \%$ of GCB subtype and $54.5 \%$ of non-GCB subtype $(p=0.028)$. Survival was significantly lower in the non-GCB subtype (log-rank test $p=0.003)$. The EBV frequency was about $3 \%$ as it is reported in Western populations. The frequency of DEL status was $8.7 \%$, indicating that it was associated with inferior survival $(p=0.045)$. De novo CD $5+D L B C L$ ratio as $13 \%$ and it was also associated with inferior survival $(p=0.013)$. We also found CD30+ DLBCL ratio as $11.5 \%$, but we could not establish a significant relationship with prognosis.

Conclusion: DLBCL-NOS requires detailed subtyping and elaboration of prognostic factors. The frequency of DEL status and De novo CD5+ DLBCL indicated that it was associated with inferior survival. However, we could not establish a meaningful relationship of CD30+ DLBCL with prognosis." Three EBV positive cases were identified and two of them were classified as 'EBV positive large B cell lymphoma' according to the WHO 2017 revised 4th edition.
\end{abstract}

Key words: Diffuse large-cell lymphoma, prognostic factors, survival
Cite this article as: Bahar AY, Kazanci U. EBV Incidence in Diffuse Large B-Cell Iymphoma: A Single Center Descriptive Study. Selcuk Med J 2020;36(2): 129-137
Disclosure: None of the authors has a financial interest in any of the products, devices, or drugs mentioned in this article. The research was not sponsored by an outside organization. All authors have agreed to allow full access to the primary data and to allow the journal to review the data if requested. 


\section{INTRODUCTION}

Diffuse large B-cell lymphoma (DLBCL) is a neoplasm, vast majority biologically heterogeneous, characterized by a diffuse growth pattern of medium to large sized B lymphoid cells, with some morphological variants, molecular subtypes, and distinct disease entities. This heterogeneous group is defined as DLBCL-NOS (1). Since clinical and prognostic heterogeneity (such as biological heterogeneity) is observed in DLBCL patients, it is vital to determine the prognostic and predictive factors that will shed light on the progress of the disease. Among the clinical features, patient age, stage, and International Prognostic Index (IPI) score are the most valuable ones associated with inferior outcome (1). Although new agents are introduced in the treatment, the standard protocol is still rituximab plus cyclophosphamide, doxorubicin, vincristine, and prednisolone (R-CHOP). The revised IPI score has been shown to be more successful in estimating survival in DLBCL patients treated with R-CHOP (2).

Current studies emphasize the prognostic significance of some immunohistochemical markers. However, controversies are often seen in the results of these studies. 2017 WHO Revised 4th edition emphasized the need to develop biomarkers that would influence the initial or subsequent choice of therapeutic approach in DLBCL (1). Two molecular subtypes have been defined according to the DLBCL cell origin (i.e., Germinal Center B-cell (GCB) subtype and Activated B-Cell (ABC) / Non-GCB subtype). Profiling studies of gene expression show that approximately $10-15 \%$ cases unincorporated/unclassified in these two subtypes are present (3). Clinical trials suggest adding bortezomib, lenalidomide, and ibrutinib to the treatment of R-CHOP in the ABC subtype (4-8). Although they cannot identify unclassifiable groups, immunohistochemical algorithms used to determine the cell origin remain an essential alternative when gene expression techniques cannot be achieved due to the influence of the choice of the cell origin on the choice of treatment $(1,3,9)$.

De novo CD5 + DLBCL has been associated with high-risk clinical features and inferior outcome, especially in studies conducted in Asian countries (10). The double-expression of MYC and BCL-2 proteins has been associated with inferior survival in many studies $(11,12)$. CD30 positive, Epstein-Barr Virus (EBV) negative DLBCLs (excluding primary mediastinal large B-cell lymphoma) were associated with a favorable outcome $(13,14)$. They are also likely to benefit from anti-CD30 therapies (1). In this study, we aimed to reevaluate and discuss the DLBCLNOS prognostic and predictive factors, published in the WHO Classification of Tumors of Hematopoietic and Lymphoid Tissues, Revised 4th edition (2017) for DLBCL patients who have been treated with R-CHOP in our center.

\section{PATIENTS AND METHODS}

Patients with DLBCL-NOS diagnosed in our hospital between 2007-2017 and treated with R-CHOP were included in the study. Of the participants, 109 patients with a known autoimmune disease, previous low-grade lymphoma diagnosis, transplantation history, $\mathrm{HIV}, \mathrm{HBV}, \mathrm{HCV}$ serology positivity, insufficient material, or incomplete clinical information were excluded. The patients were independently evaluated by two pathologists as to morphology and immunohistochemistry (IHC). Immunohistochemical panel; CD20, CD3, CD5, CD10, BCL-2, BCL-6, MYC, MUM-1, and Ki-67. Four patients were excluded from the study because of no consensus on the diagnosis. Clinical and demographic data of the remaining 104 patients were obtained from electronic medical records (age, gender, Ann Arbor stage, PET/CT scan reports, ECOG performance scores, and serum LDH levels). Ann Arbor staging was performed by PET/CT scan. The Revised International Prognostic Index (R-IPI) score was calculated. The overall survival time was calculated as the time between diagnosis and death. The study was approved by the Ethics Committee of KSU University Faculty of Medicine (IRB number: 05: 2017/16, Date: 11.10.2017)

\section{Immunohistochemistry}

The recent IHC preparations of the patients were reviewed during the reevaluation process. 3.5- $\mu \mathrm{m}$ thick sections were prepared for IHC staining. The Ventana Benchmark XT autostainer (Roche Diagnostics) was used for all IHC stainings. Cases with missing panels and those requiring repetition were revealed, and $\mathrm{Ki}-67$ status, germinal and nongerminal status (CD10, BCL-6, MUM-1) according to Hans classifier (15), MYC/BCL-2 double expressor status, CD5 status, CD30 status, P53 status, and EBV status (LMP-1, EBNA-2) were evaluated in all cases. The IHCs used, and cut-off values are summarized in Table 1.

\section{In-situ Hybridization}

In situ hybridization was done using the Ventana Benchmark XT autostainer - EBV encoded RNA $(E B E R)$ stained preparations from 3.5- $\mu$ m-thick 
Table 1. Expression ratios and cut-off values for the immunohistochemical and in situ hybridization markers, and their correlation with overall survival (log-rank test).

\begin{tabular}{llllll}
\hline Marker & Clone & Dilution & Cut-off \% & Expression n & OS p-value \\
\hline Ki-67 & Ventana 30-9 & RTU & $70 \%$ & $42 / 104$ & $\mathrm{p}=0.637$ \\
P53 & Ventana Bp53-11 & RTU & $50 \%$ & $16 / 104$ & $\mathrm{p}=0.405$ \\
CD10 & Ventana SP67 & RTU & $30 \%$ & $20 / 104$ & $\mathrm{p}=0.102$ \\
MUM-1 & Ventana MRQ-43 & RTU & $30 \%$ & $45 / 104$ & $\mathrm{p}=0.186$ \\
BCL-6 & Ventana GI191E/A8 & RTU & $30 \%$ & $69 / 104$ & $\mathrm{p}=0.046$ \\
BCL-2 & Ventana 124 & RTU & $50 \%$ & $69 / 104$ & $\mathrm{p}=0.003$ \\
MYC & Ventana Y69 & RTU & $40 \%$ & $13 / 104$ & $\mathrm{p}=0.067$ \\
CD5 & Ventana SP19 & RTU & $50 \%$ & $14 / 104$ & $\mathrm{p}=0.013$ \\
CD30 & Ventana Ber-H2 & RTU & $20 \%$ & $12 / 104$ & $\mathrm{p}=0.198$ \\
LMP-1 & Ventana CS1-4 & RTU & $20 \%$ & $1 / 104$ & \\
EBNA-2 & Novus PE2 & 1/100 & $20 \%$ & $1 / 104$ & \\
EBER-ISH & Ventana 1 DNP Probe & RTU & $20 \%$ & $2 / 104$ &
\end{tabular}

RTU: ready to use; OS: overall survival; EBER-ISH: Ebstein-Barr Virus Encoded RNA-In situ hybridization

sections prepared from $10 \%$ formalin-fixed, paraffinembedded diagnostic biopsies. EBER was considered positive when nuclear staining was seen in more than $20 \%$ of tumor cells (16).

\section{Statistical Analysis}

The relationship between categorical variables was analyzed by the Pearson Chi-Square test, while the overall survey (OS) was done using the KaplanMeier method (log-rank). The Cox-regression test used performed for multivariate analysis. A p-value $<0.05$ was considered as statistically significant. All statistical analyses were performed with the SPSS package (version 20, IBM, Chicago, USA).

\section{RESULTS}

\section{Clinicopathological characteristics}

Patient characteristics are summarized in Table 2. The study included 56 men (53.8\%) and 48 women $(46.2 \%)$. The median age was 64.5 years (range, 4-93 years) and $58.7 \%$ of the cases were above 60 . In $59.6 \%$ of the patients, the disease had a nodal beginning, whereas in $40.4 \%$ of the patients it had an extranodal presentation. Of the patients, 35.6\% were at an advanced stage (stage III-IV), $76 \%$ had high $\mathrm{LDH}, 56.6 \%$ had ECOG PS $\geq 2$, and $48.1 \%$ an R-IPI score $\geq 3$. Median follow-up was 26.6 months (range, 1.6-156 months). R-CHOP was the main chemotherapy regimen in all DLBCL-NOS patients. There were statistically significant relationship with overall survival and R-IPI score, Ann Arbor stage, advanced age, high LDH, ECOG PS (Figure 1).

\section{Evaluation of the results according to cell of origin / GCB or non-GCB}

Of the 104 patients, 49 (47.1\%) had GCB subtype, $55(52.9 \%)$ had non-GCB subtype phenotype. 20 patients (19.2\%) were CD10 positive, 69 (66.3\%) were BCL-6 positive, and 45 (43.3\%) were MUM-1 positive. The phenotype distributions were CD10BCL-6+ MUM-1- phenotype ( $n=27,25.9 \%)$, CD10+ BCL-6+ MUM-1- phenotype ( $n=11,10.5 \%), C D 10$ + BCL-6+ MUM-1+ c $(n=8,7.6 \%)$, CD10 + BCL-6-
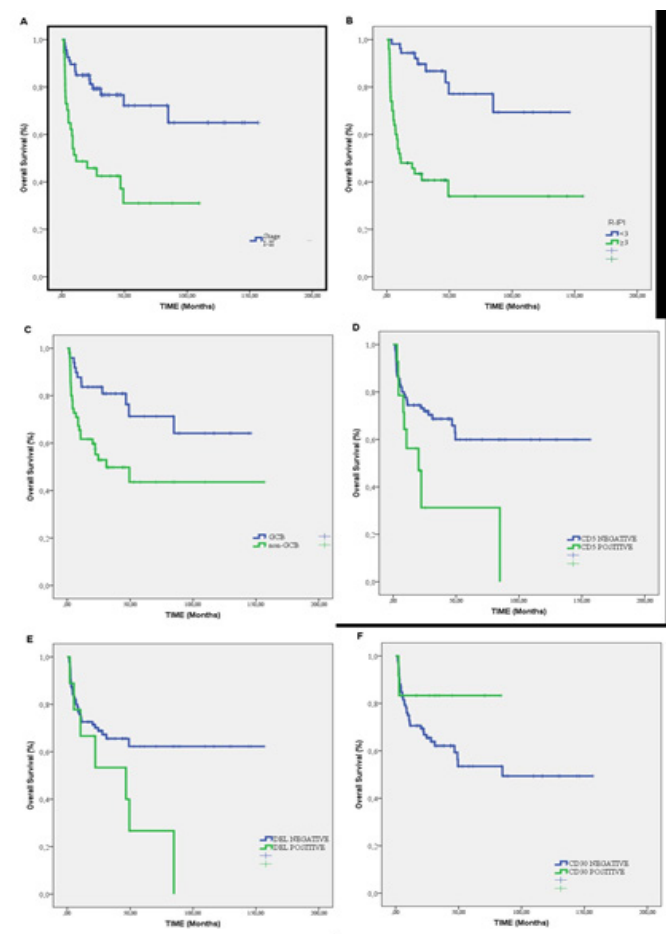

Figure 1. Kaplan-Meier analysis of overall survival (OS) based on clinicopathologic factors (A) OS for Ann Arbor stages $(p=0.001)$ (B) OS for R-IPI scores $(p=0.0001)(C)$ OS for GCB subtype vs. non-GCB subtype $(p=0.003)$ (D) OS for CD5 positive vs. negative $(p=0.013)(E)$ OS for $D E L$ vs. non-DEL $(p=0.045)(F)$ OS for CD30 positive vs. negative $(p=0.198)$ 
MUM-1+ phenotype $(n=1,1 \%)$ in the GCB subtype and CD10 - BCL-6+ MUM-1+ phenotype $(n=23$, 22.1\%), CD10 - BCL-6- MUM-1- phenotype ( $n=21$, $20.1 \%)$, and CD10 - BCL-6- MUM-1+ phenotype $(n=13,12.5 \%)$ in the non-GCB subtype. While there was no significant difference in the expression of CD5, P53, MYC, MYC+/BCL-6+, MYC+/BCL-2+ $(12 \%$ vs. $5 \%, p=0.219)$, Ki-67, and CD30 between GCB subtype and non-GCB subtypes, there was a significant difference concerning BCL-2 expression (55\% vs. $76.3 \%, p=0.022)$ and CD5 expression $(4 \%$ vs. $21 \%, p=0.008)$.

There was no significant difference between GCB subtype and non-GCB subtypes regarding age, sex, primary site, and ECOG performance score. However, there was a significant difference concerning high LDH ( $\geq 220 \mathrm{IU} / \mathrm{L})$, high stage (III-IV), and R-IPI score. While high LDH was observed in $63 \%$ of the GCB subtype, it was present in $87 \%$ of the non-GCB subtypes $(p=0.004)$. High stage (III-IV) was present in $26.5 \%$ of the GCB subtype and in $43.6 \%$ of non-GCB subtype $(p=0.049)$. High R-IPI score (score 4-5) was observed in $40 \%$ of GCB subtype and $54.5 \%$ of non-
GCB subtype $(p=0.028)$. Survival was significantly lower in the non-GCB subtype (log-rank test $p=0.003$, Figure 1).

\section{Evaluation of the results according to CD5}

Patients with a history of Chronic lymphocytic leukemia/small lymphocytic lymphoma or mantle lymphoma were excluded from the study. CD5 positivity was observed in 14 of the 104 patients $(13 \%)$ with DLBCL. There was no relationship between CD5 and sex, age, ECOG performance score, LDH level, primary site, high stage (III-IV), and R-IPI score. CD5 positivity was observed in $4 \%$ $(n=2 / 14)$ of the GCB subtype versus $21 \%(n=12 / 14)$ of the non-GCB subtype, and the difference was statistically significant $(p=0.008)$. However, there was no significant relationship between CD5 and CD10, MUM-1, BCL-2, MYC+/BCL-2+, BCL-6, P53, Ki-67 or MYC. Survival was significantly lower in the CD5 positive group (log-rank test $p=0.013$, Figure 1).

\section{Evaluation of the results according to $\mathrm{MYC/}$} $B C L-2$

Of the 104 cases $13(12.5 \%)$ had MYC, $69(66.3 \%)$ had BCL-2, 68 (65.3\%) had BCL-6, 9 (8.7\%) had

Table 2. Patient characteristics.

\begin{tabular}{|c|c|c|c|}
\hline Criteria & Range & n (\%) & OS p-value \\
\hline \multicolumn{4}{|l|}{ Gender } \\
\hline Male & & $56(53.8 \%)$ & $p=0.735$ \\
\hline Female & & $48(46.2 \%)$ & \\
\hline \multicolumn{4}{|l|}{ Age } \\
\hline$<60$ & 4 to 93 & $43(41.3 \%)$ & $p=0.041$ \\
\hline$\geq 60$ & & $61(58.7 \%)$ & \\
\hline \multicolumn{4}{|c|}{ Ann-Arbor Stage } \\
\hline$|-| \mid$ & & $67(64.4 \%)$ & $p=0.0001$ \\
\hline III-IV & & $37(35.6 \%)$ & \\
\hline \multicolumn{4}{|l|}{ LDH } \\
\hline$<220$ & 128 to 2796 & $25(24 \%)$ & $p=0.001$ \\
\hline$\geq 220$ & & $79(76 \%)$ & \\
\hline \multicolumn{4}{|l|}{ Primary Site } \\
\hline Nodal & & $62(59.6 \%)$ & $p=0.058$ \\
\hline Extranodal & & $42(40.4 \%)$ & \\
\hline \multicolumn{4}{|l|}{ R-IPI } \\
\hline 0 & & $11(10.6 \%)$ & \\
\hline 1 & & $18(17.3 \%)$ & \\
\hline 2 & & $23(22.1 \%)$ & $p=0.001$ \\
\hline 3 & & $31(29.8 \%)$ & \\
\hline 4 & & $11(10.6 \%)$ & \\
\hline 5 & & $10(9.6 \%)$ & \\
\hline \multicolumn{4}{|l|}{ ECOG } \\
\hline 0 & & $10(9.6 \%)$ & \\
\hline 1 & & $36(34.6 \%)$ & \\
\hline 2 & & $29(27.9 \%)$ & $p=0.001$ \\
\hline 3 & & $16(15.4 \%)$ & \\
\hline 4 & & $13(12.5 \%)$ & \\
\hline
\end{tabular}

LDH: lactate dehydrogenase; R-IPI: Revised International Prognostic Index score; ECOG: Eastern Cooperative Oncology Group performance score; OS: overall survival 
Table 3. Summary of EBV-Positive DLBCL cases

\begin{tabular}{llll}
\hline & Case 1 & Case 2 & Case 3 \\
\hline Age & 4 & 35 & 84 \\
Gender & Male & Male & Female \\
Primary Site & Nodal & Nodal & Nodal \\
IPI Score & 0 & 1 & 3 \\
Stage & 1 & 1 & 3 \\
GCB & GCB & non-GCB & non-GCB \\
LMP-1 & $>50 \%$ & $>0 \%$ & $>0 \%$ \\
EBNA-2 & $>50 \%$ & $>0 \%$ & $>0 \%$ \\
EBER & $>0 \%$ & $\geq 20 \%$ & $\geq 20 \%$ \\
Ki-67 & $40 \%$ & $35 \%$ & $50 \%$ \\
MYC & $5 \%$ & $10 \%$ & Negative \\
CD30 & Negative & Positive & Negative \\
CD5 & Negative & Negative & Positive \\
CD10 & Positive & Negative & Negative \\
BCL-2 & Negative & Negative & Positive \\
BCL-6 & Positive & Negative & Negative \\
Life Status & Alive & Alive & Dead \\
Follow-Up & 130 months & 58 months & 20 months \\
\hline
\end{tabular}

MYC+/ BCL-2+, 9 (8.7\%) had MYC+/ BCL-6+, and 7 $(6.7 \%)$ had $\mathrm{MYC}+/ \mathrm{BCL}-2+/ \mathrm{BCL}-6+$. When the three cases with $\mathrm{MYC}+/ \mathrm{BCL}-2-/ \mathrm{BCL}-6+$ were reevaluated concerning Burkitt's lymphoma, the Ki-67 score was less than $90 \%$ in all cases and none presented the starry-sky pattern. There was no relationship concerning the variables in the $\mathrm{MYC}+/ \mathrm{BCL}-2+$ nine cases.

All the seven MYC+/BCL-2+/BCL-6+ cases were women $(7 / 7, p=0.03)$ and five were in the MUM-1 positive. Significant less survival was observed in the MYC+/ BCL-2+ positive group (log-rank test $p=0.045$, Figure 1).

\section{Evaluation of the results according to CD30}

CD30 expression was positive in 12/104 cases with a cut off of $\geq 20 \%$. There was no relationship could be demonstrated with the immunohistochemical variables and clinical parameters. Also, no difference concerning survival could be demonstrated between the CD30 positive and negative groups (Figure 1).

\section{Proliferation}

The mean Ki-67 proliferation index of our series was $62.3 \% \pm 21.7$ (median $70.0 \%$, range 15-95). For a $>70.0 \%$ cut-off value, $40.4 \%$ of the cases had high Ki-67 scores. There was no statistically significant relationship between high the Ki-67 score and clinical findings, immunohistochemical markers, or OS (Figure 1).

\section{Evaluation of the results according to P53}

There was a high p53 expression in 16 (15.4\%) cases. However, no significant relationship could be demonstrated with the clinical parameters and immunohistochemical markers. Although the survival seemed to be lower in the group with high p53 expression, the difference did not reach statistical significance $(p=0.405$, Figure 1$)$.

\section{Evaluation of the results according to EBV}

While we observed $>0 \%$ positivity in at least one of the three markers in $6 / 104(5.6 \%)$ cases, $\geq 20 \%$ positivity was observed in $3 / 104(2.8 \%)$ cases and connected to EBV. For the $\geq 20 \%$ cut-off, EBER positivity was observed in two cases, and LMP-1 and EBNA-2 positivity each in one case (Figure 2). Features of these cases are summarized in Table 3.

\section{DISCUSSION}

DLBCL is the most common type of B-cell lymphoma on a worldwide basis. Although sub-groups are defined by morphological, biological and clinical studies, many cases show biological heterogeneity. Therefore, there are no clear and accepted criteria for defining subgroups. In the management of the disease, different methods are needed to determine the risk of mortality and to plan the treatment. For this purpose, some molecular markers are used as prognostic factors in certain patient groups, but investigations continue concerning additional factors related to the biologic behavior of the tumor. The International Prognostic Index Score (IPI score), which aims to determine high-risk patients by evaluating five clinical variables (age, ECOG performance score, serum LDH levels, stage, and extranodal involvement) preserves its value in predicting the prognosis. Thus, we evaluated our patients with the revised-IPI score 
Table 4. Multivariate analysis of prognostic factors, which were significant in univariate analysis.

\begin{tabular}{llll}
\hline & Hazard Ratio & p-value & 95\% confidence interval \\
\hline Advanced Age ( $\geq 60)$ & 1.33 & 0.481 & $0.6-2.94$ \\
High R-IPI Score ( $\geq 3)$ & 5.51 & $<0.001$ & $2.18-13.91$ \\
non-GCB Subtype & 2.55 & 0.014 & $1.19-5.46$ \\
High stage (3-4) & 2.61 & 0.015 & $1.20-5.67$ \\
CD5+ & 2.04 & 0.103 & $0.86-2.94$ \\
DEL (MYC+/BCL-2+) & 5.03 & $<0.001$ & $1.86-13.9$ \\
\hline
\end{tabular}

R-IPI: Revised International Prognostic Index score; DEL: Double expressor lymphoma

developed by Sehn et al (2). The R-IPI score was $\geq 3$ in $48.1 \%$ of the cases. We observed a significant

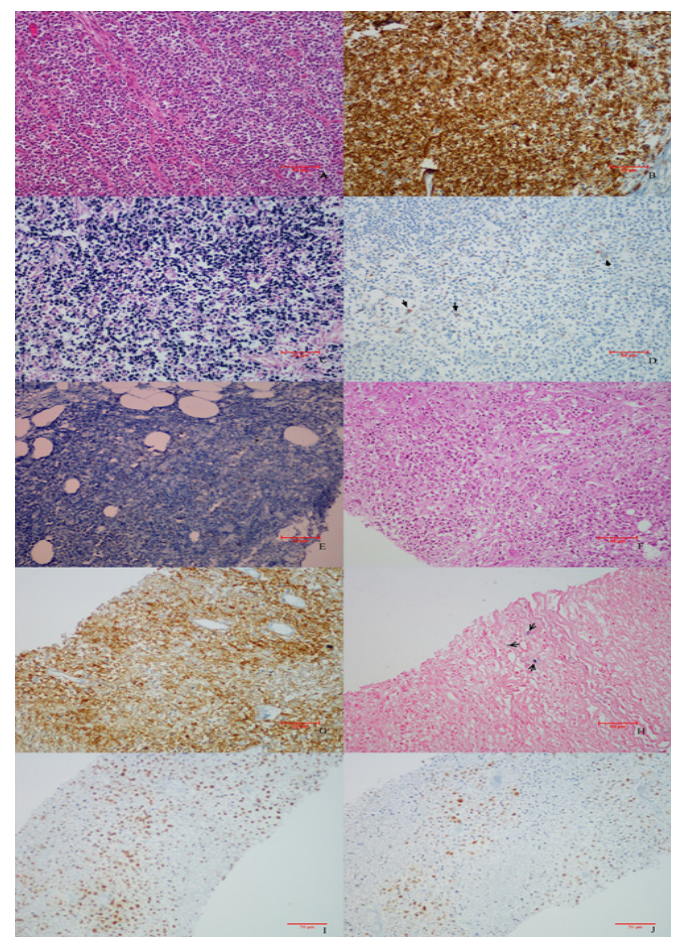

Figure 2. EBV positive diffuse large B-cell lymphoma. Case 2, an 84-year-old female patient who presented with inguinal lymphadenopathy. (A) Microscopic examination demonstrate diffuse proliferation of medium to large sized lymphoid cells (Hematoxylin and Eosin, original magnification x200) (B) The tumor cells are positive for CD20 (IHK, original magnification $x 200$ ), (C) EBER in situ hybridization positive for $>\% 20$ of tumor cells, (EBER-ISH, original magnification x200) (D) LMP-1 and (E) EBNA-2 were positive for $>\% 0$ of tumor cells, (IHK, original magnification $\times 200$ ) Case 2, a 4-year-old male patient who had cervical lymphadenopathy $(F)$ On microscopic examination there was a diffuse infiltration of medium to large sized lymphoid cells in a sclerotic and necrotic background (Hematoxylin and Eosin, original magnification x200) (G) the tumor cells were positive for CD20 diffusely (IHK, original magnification $\mathrm{x} 200)(\mathrm{H})$ EBER-ISH was positive in very few cells (EBER-ISH, original magnification x200), (I) LMP1 and $(J)$ EBNA-2 were positive for $>\% 20$ of tumor cells (IHK, original magnification $\mathrm{x} 200$ ). relationship between the high R-IPI scores and low OS. The R-IPI score was an independent risk factor in the survey (Table 4). We encountered higher proportions of non-GCB subtype (52.9\%). It is known that this ratio shows geographical changes. It has been reported in many studies that the rate of the GCB subtype is lower in Asian countries (17). Other studies from Turkey $(18,19)$ reported non-GCB as 45.2 to $48.7 \%$. These classifications are based on the two-system immunohistochemistry and do not include unclassifiable types. It was determined that predicting the prognosis with gene expression profiling is more valuable than immunohistochemical methods (9). BCL-2 positivity was significantly higher (55\% to $87 \%$ ) in the non-GCB subtype. We found in the non-GCB subtype significant correlations between high LDH levels, advanced stage, high IPI scores, and low OS. These findings are consistent with the literature (1).

Different results have been reported in the literature about the frequency of De novo CD5+ DLBCL and its prognostic significance. In the series of Chuang et al. (20), De novo CD5+ DLBCL was present in 5.2\% and was found as an independent predictive factor of poor prognosis. In the series of Ennishi et al., the incidence of De novo CD5+ DLBCL was found as $9 \%$, and it was defined as an independent poor prognostic factor (21). Xu-Monette et al. have reported the prevalence of De novo CD5+ DLBCL in Western countries as $5.5 \%$ and defined it as an independent poor prognostic factor too (10). In our study, we observed De novo CD5+ DLBCL in 14/104 (13\%); however, patients in this sample were older (11/14), non-GCB subtype (12/14), and lower OS $p=0.008$. At the same time, the multivariate analysis did not reveal De novo CD5+ DLBCL as an independent risk factor for survival (Table 4). Hence, we postulate that due to higher elderlies, and non-GCB subtype, in our series, the De novo CD5+ DLBCL frequency could not be determined as an independent prognostic factor and was present in higher frequency compared to the literature. 
Immunohistochemically, high expression of MYC and BCL-2 protein was defined as double-expressor lymphoma (DEL), and in some studies, the incidence of DLBCL was approximately $20 \%(22,23)$. In these studies, DEL was reported as poor prognosis and related with non-GCB subtype. In our study, a $7.9 \%$ double expressor (MYC+/BCL-2+) lymphoma was detected in the case series, but no significant relationship was found with other clinical parameters. We observed that the overall survival was significantly lower in the double-expressor DLBCL group and that it was an independent prognostic factor in terms of survival (Table 4). In 7/9 of the DEL cases, the Ki67 proliferation index was high, there was MUM-1 positivity in $7 / 9$, and non-GCB origin in $7 / 9$. Although non-GCB subtype was observed in $7 / 9$ cases, no statistically significant relationship was observed $(p=$ 0.077 ). CD30 positivity was not observed in any of the nine cases.

However, the use of immunohistochemical markers to identify risky patients rather than direct treatment has come to the forefront (23). Sarkozy and colleagues found that immunohistochemical markers were not specific for the diagnosis of doublehit lymphomas that they reported being associated with inferior surveys in their studies and indicated the necessity of Fluorescence In Situ Hybridization (FISH) analysis (12). Because of the biological and clinical differences, all b cell lymphomas that have a MYC rearrangement in a combination with a BCL2 and/or a BCL6 rearrangement classified as 'High grade b cell lymphoma with MYC and BCL2 and/or BCL6 rearrangements' (so-called double hit and triple hit lymphomas), in 2017 WHO Revised 4th edition. With a FISH or comparable method for testing MYC rearrangement is mandatory for exclude this entity (1).

The MYC / BCL-2 double rearrangement with FISH was reported as $3.09 \%(n=3 / 97)$ in another study conducted by Akkaya et al. in Turkey (19). Differently, Steiger et al. showed that DEL was associated with poor prognosis and that immunohistochemical double-expressor status was still important in DLBCL (24). Hao et al. (25) reported CD30+ DLBCL incidence as $15 \%$, and linked it to poor prognosis and non-GCB subtype. Hu et al. (13) on the other hand, demonstrated a $14 \%$ frequency and association with a favorable prognosis. 12/104 (11.5\%) CD30+ cases were observed in our series, and there was no significant relationship was found between clinical variables and other IHC markers. One case was
EBER ISH positive. Interestingly, in our study, no CD5 or DEL positivity was observed in any of the CD30 positive cases.

P53 expression in DLBCL has been reported at 20$60 \%$ using different cut-off values (1). P53 has been associated with poor prognosis in some studies (26). In our study, elevated P53 expression was detected in 16 cases $(15 \%)$, and no statistically significant relationship was observed between P53 expression and clinical parameters, or IHC markers. In DLBCL, the EBV frequency was observed as $5-15 \%$ in Asian and Latin American countries while $<5 \%$ in Western countries $(1,14,27)$. Uner et al. reported EBER ISH positivity as $5,3 \%$ in DLBCL in the Turkish population and classified $3,5 \%$ cases "EBV-positive DLBCL of the elderly" according to the WHO 2008 classification criterion (29). Significant EBV positivity was detected in 3 of 102 cases ( $\% 2.9$, cut-off> $20 \%$ ) in our study. The clinicopathological data of our cases are summarized in Table 3 and show heterogeneous features. On the other hand, some studies suggest age 45 as the cutoff for prognosis in EBV-positive DLBCL (1). In fact, of our patients, those older than 45 years of age died while others were still alive.

Formerly designated as EBV-positive DLBCL of the elderly, in the $2008 \mathrm{WHO}$ 4th edition, was changed to EBV-positive DLBCL-NOS because the disease was seen in a wider range, in WHO Revised 4th edition. In situ hybridization for EBV-encoded small RNA (EBER) is essential for the diagnosis of EBV-positive DLBCL. Considering these criteria, the diagnosis of EBV-positive DLBCL is appropriate for case 2 and 3 summarized in table 3 . In the first case, acute or recent EBV infection could not be excluded. As mentioned earlier, DLBCL -NOS is a morphological, biological, and clinically heterogeneous disease. This heterogeneous group requires subtyping distinct disease entity definition. In contemporary studies, CD5+ DLBCL, DEL, and CD30+ DLBCL stand out as distinct entities. We observed very little commonality between these groups in our sample. The common expression was no present $(n=0 / 35)$ and there were three cases positive for CD5+ and DEL $(n=3 / 23)$. A large majority of the cases was not included in any of these entities ( $n=69 / 104)$. When we studied this group as a separate cohort, the GCB subtype ratio $(n=35 / 69)$ was elevated, and no change regarding significant prognostic factors was observed. Our study supports the studies suggesting the classification of de novo cd5 positive DLBCL and CD30 positive DLBCL groups as a separate entity than DLBCL- 
NOS.

\section{CONCLUSION}

As mentioned above, DLBCL-NOS is a clinically morphologically and biologically heterogeneous lymphoid neoplasm. Clinically, patient age, stage of disease and IPI score are significant factors affecting the surveillance. The prognostic significance of cell of origin (GCB, $A B C$, and unclassifiable subtypes) has been clearly demonstrated in current metaanalyses and phase III clinical trials. However, most immunohistochemical markers reported for prognostic significance have not yet been strongly validated. Besides, the expression of these markers shows significant geographical differences. In this study, we investigated the frequency and prognostic significance of these immunohistochemical markers in DLBCL-NOS which were discussed in the WHO 2017 revised 4th edition. The fact that it is single centered and mostly based on immunohistochemical findings limits our study. However, we believe that this informations will contribute to the literature and in particularly to the clinicians interested in DLBCL-NOS from Turkey.

Conflict of interest: Authors declare that there is no conflict of interest between the authors of the article.

Financial conflict of interest: Authors declare that they did not receive any financial support in this study.

Address correspondence to: Abdulkadir Yasir Bahar, Kahramanmaraş Sütçü İmam University School of Medicine, Department of Pathology,

Kahramanmaraş, Turkey

e-mail: ayasirbahar@gmail.com

\section{REFERENCES}

1. Swerdlow SH, Campo E, Harris NL, et al. WHO classification of tumours of haematopoetic and lymphoid tissues (Revised 4th edition). IARC Press, 2017;291-297,304-6

2. Sehn LH, Berry $B$, Chhanabhai $M$, et al. The revised international prognostic index (R-IPI) is a better predictor of outcome than the standard IPI for patients with diffuse large B-cell lymphoma treated with R-CHOP. Blood 2007;109(5):1857-61.

3. Scott DW, Mottok A, Ennishi D, et al. Prognostic significance of diffuse large B-cell lymphoma cell of origin determined by digital gene expression in formalin-fixed paraffin-embedded tissue biopsies. J Clin Oncol 2015;10;33(26):2848.

4. Dunleavy K, Pittaluga S, Czuczman MS, et al. Differential efficacy of bortezomib plus chemotherapy within molecular subtypes of diffuse large B-cell lymphoma. Blood 2009;113(24):6069-76.

5. Mathews GL, Guha R, Shinn P, et al. High-throughput combinatorial screening identifies drugs that cooperate with ibrutinib to kill activated B-cell-like diffuse large B-cell lymphoma cells. Proceedings of the National Academy of Sciences of the United States of America 2014;111(6):2349.

6. Nowakowski GS, LaPlant B, Macon WR, et al. Lenalidomide combined with R-CHOP overcomes negative prognostic impact of non-germinal center B-cell phenotype in newly diagnosed diffuse large B-cell lymphoma: A phase II study. J Clin Oncol 2014;33(3):251-7.

7. Offner F, Samoilova O, Osmanov E, et al. Frontline rituximab, cyclophosphamide, doxorubicin, and prednisone with bortezomib (VR-CAP) or vincristine (R-CHOP) for nonGCB DLBCL. Blood 2015;126(16):1893-901.

8. Wilson $\mathrm{WH}$, Young RM, Schmitz R, et al. Targeting $B$ cell receptor signaling with ibrutinib in diffuse large $B$ cell lymphoma. Nature medicine 2015;21(8):922.

9. Read JA, Koff JL, Nastoupil LJ, et al. Evaluating cell-of-origin subtype methods for predicting diffuse large B-cell lymphoma survival: A meta-analysis of gene expression profiling and immunohistochemistry algorithms. Clinical Lymphoma, Myeloma and Leukemia 2014;14(6):460-7.

10. Xu-Monette ZY, Tu M, Jabbar KJ, et al. Clinical and biological significance of de novo CD5+ diffuse large B-cell lymphoma in Western countries. Oncotarget 2015;6(8):5615.

11. Molina, TJ, Canioni, D, Copie-Bergman, C, et al. Young patients with non-germinal center B-cell-like diffuse large B-cell lymphoma benefit from intensified chemotherapy with ACVBP plus rituximab compared with $\mathrm{CHOP}$ plus rituximab: analysis of data from the Groupe d'Etudes des Lymphomes de I'Adulte/Lymphoma Study Association phase III trial LNH 03-2B. J Clin Oncol 2014;32(35):3996-4003.

12. Sarkozy C, Traverse-Glehen A, Coiffier B. Double-hit and double-protein-expression lymphomas: Aggressive and refractory lymphomas. The Lancet Oncology 2015;16(15):e555-67.

13. Hu S, Xu-Monette ZY, Balasubramanyam A, et al. CD30 expression defines a novel subgroup of diffuse large B-cell lymphoma with favorable prognosis and distinct gene expression signature: A report from the International DLBCL Rituximab-CHOP Consortium Program Study. Blood 2013;121(14):2715-24.

14. Slack GW, Steidl C, Sehn LH, et al. CD30 expression in de novo diffuse large B-cell lymphoma: a population-based study from British Columbia. British journal of haematology 2014;167(5):608-17.

15. Hans CP, Weisenburger DD, Greiner TC, et al. Confirmation of the molecular classification of diffuse large B-cell lymphoma by immunohistochemistry using a tissue microarray. Blood 2004;103(1):275-82.

16. Park S, Lee J, Ko YH, et al. The impact of Epstein-Barr virus status on clinical outcome in diffuse large B-cell lymphoma. Blood 2007;110(3):972-8.

17. Ichiki A, Carreras J, Miyaoka M, et al. Clinicopathological analysis of 320 cases of diffuse large B-cell lymphoma using the hans classifier. Journal of clinical and experimental hematopathology 2017;57(2):54-63.

18. Ozbalak M, Ar MC, Tuzuner N, et al. Detailed analysis of diffuse large B cell lymphoma patients: A single-center, retrospective study. ISRN hematology 2013;30;2013.

19. Akkaya B, Salim O, Akkaya H, et al. C-MYC and BCL2 translocation frequency in diffuse large B-cell lymphomas: A study of 97 patients. Indian Journal of Pathology and 
Microbiology 2016;59(1):41.

20. Chuang WY, Chang H, Shih LY, et al. CD5 positivity is an independent adverse prognostic factor in elderly patients with diffuse large B cell lymphoma. Virchows Archiv 2015;467(5):571-82.

21. Ennishi D, Takeuchi K, Yokoyama M, et al. CD5 expression is potentially predictive of poor outcome among biomarkers in patients with diffuse large B-cell lymphoma receiving rituximab plus CHOP therapy. Annals of oncology 2008;19(11):1921-6.

22. Green TM, Young KH, Visco C, et al. Immunohistochemical double-hit score is a strong predictor of outcome in patients with diffuse large B-cell lymphoma treated with rituximab plus cyclophosphamide, doxorubicin, vincristine, and prednisone. J Clin Oncol 2012;30: 3460-7.

23. Johnson NA, Slack GW, Savage KJ, et al. Concurrent expression of MYC and BCL2 in diffuse large B-cell lymphoma treated with rituximab plus cyclophosphamide, doxorubicin, vincristine, and prednisone. J Clin Oncol 2012;30:3452-9.

24. Staiger AM, Ziepert $M$, Horn $H$, et al. Clinical impact of the cell-of-origin classification and the MYC/BCL2 dual expresser status in diffuse large B-cell lymphoma treated within prospective clinical trials of the German highgrade non-Hodgkin's lymphoma study group. J Clin Oncol 2017;22:2515-26.
25. Hao X, Wei X, Huang $F$, et al. The expression of CD30 based on immunohistochemistry predicts inferior outcome in patients with diffuse large B-cell lymphoma. PloS one 2015;10(5):e0126615.

26. Wang XJ, Jeffrey Medeiros L, Bueso-Ramos CE, et al. P53 expression correlates with poorer survival and augments the negative prognostic effect of MYC rearrangement, expression or concurrent MYC/BCL2 expression in diffuse large B-cell lymphoma. Modern Pathology 2016;30:194.

27. Ok CY, Li L, Xu-Monette ZY, et al. Prevalence and clinical implications of Epstein-Barr virus infection in de novo diffuse large B-cell lymphoma in Western countries. Clinical Cancer Research 2014;20(9):2338-49.

28. Li ZM, Huang JJ, Xia Y, et al. High Ki-67 expression in diffuse large B-cell lymphoma patients with non-germinal center subtype indicates limited survival benefit from R-CHOP therapy. European journal of haematology 2012;88(6):510-7.

29. Uner A, Akyurek N, Saglam A, et al. The presence of epsteinbarr virus (EBV) in diffuse large B-cell lymphomas (DLBCLs) in Turkey: Special emphasis on 'EBV-positive DLBCL of the elderly'. APMIS, 2011:119(4-5),309-16. 